\title{
Program Diet Berdasarkan Jenis Olahraga Berbasis Android
}

\author{
Ketut Wijaya Kusuma1, Fatoni ${ }^{2}$, Hadi Syaputra*3 \\ 1,2,3 Informatics Departement, Bina Darma University, Palembang, Indonesia \\ Email: ${ }^{1}$ ketutwijayakusuma92@gmail.com, ${ }^{2}$ fatoni@binadarma.ac.id, ${ }^{3}$ hadisyaputra@binadarma.ac.id
}

\begin{abstract}
Sports is one of the physical activities that are good for health and fitness. By exercising, we can minimize the risk of developing disease. By exercising too, we can lose weight, keep our body weight stable and ideal, and many other benefits of exercise. Today, sports are carried out not only to lose weight or maintain health, but also as a means of recreation to channel hobbies as well as a profession. The problem now is that diet programs are still done manually and are not chosen properly, making it difficult for sportsmen to be able to undergo a diet program effectively because it is not in accordance with the type of exercise they are struggling with. Then an application is needed that can guide them to accompany an Android-based diet program.
\end{abstract}

Keywords: diet program, type of exercise, Android

\section{PENDAHULUAN}

Kesehatan merupakan kebutuhan utama bagi setiap manusia. Kesehatan sendiri bisa diperoleh dengan cara menjaga pola makan dan olahraga teratur. Namun karena kurangnya pengetahuan masyarakat mengenai pola makan seimbang,menjadikan mereka kesulitan dalam mengatur kondisi fisik. (Boot, 1994). Kondisi fisik adalah salah satu kesatuan utuh dari komponenkomponen yang tidak dapat dipisahkan begitu saja, baik peningkatanya, pemeliharaanya. Artinya bahwa didalam usaha peningkatan kondisi fisik maka seluruh komponen tersebut harus dikembangkan, walaupun disana sini dilakukan sistem prioritas sesuai keadaan atau status tiap komponen tersebut dan untuk keperluan apa keadaan atau status yang dibutuhkan tersebut (Sajoto, 1988:53). Berdasarkan hal tersebut, maka kesehatan adalah keadaan sejahtera dari badan, jiwa, dan sosial yang memungkinkan setiap orang hidup produktif secara sosial, dan ekonomis. 


\section{Journal of Software Engineering Ampera}

Vol. 1, No. 1, February 2020 e-ISSN: 2775-2488

https://journal-computing.org/index.php/journal-sea/index

Menurut Elga (2007) Tubuh yang sehat dimulai dari berat badan yang ideal. Pada saat ini program diet merupakan suatu banyak yang diminati kalangan orang yang mempunyai berat badan yang cukup tidak ideal karena itu kebanyakan dari mereka ingin melakukan program diet. Kim dan Lennon (2006:347) mengartikan diet sebagai:"Reducation in caloric intake to lose weight". Berdasarkan definisi diatas, perilaku diet dapat diartikan sebagai kegiatan membatasi nutrisi berupa kalori dengan sengaja, yang dimaksudkan untuk mendapatkan bentuk tubuh yang lebih kurus. (Fitriyanti, 2013:12).

Olahraga merupakan salah satu aktifitas fisik yang baik untuk kesehatan dan kebugaran tubuh. Dengan berolahraga, kita dapat meminimalisir resiko terserang penyakit. Dengan berolahraga pula, kita dapat menurunkan berat badan, menjaga berat tubuh agar tetap stabil dan ideal, serta masih banyak lagi manfaat olahraga lainnya. Dewasa ini, olahraga dilakukan tidak hanya untuk menurunkan berat badan atau menjaga kesehatan saja, tapi juga dilakukan sebagai sarana rekreasi untuk menyalurkan hobi jugadapat menjadi profesi. Misalnya olahraga lari, seperti yang dimuat dalam Build Your Running Body: A Total-Body Fitness Plan for All Distance Runners, from Milers to Ultramarathoners-Run Farther, Faster, and Injury-Free ditulis oleh Pete Magill yang terbit pada tahun 2014. Adapun, olahraga secara umum dapat dilakukan dengan periodisasi terhadap latihan yang dilakukan olahragawan, seperti halnya yang dimuat pada buku Periodization Training for Sports-3rd Edition ditulis oleh Tudor Bompa yang terbit pada tahun 2015.

Untuk itu perkembangan teknologi sangat berperan dalam olahraga, sehingga membuat olahragawan dapat mengoptimalkan kegiatan olahraga misalnya hendak mengikuti program diet. Tak ingin ketinggalan perkembangan teknologi agar mampu memenuhi kebutuhan olahragawan. Hal itu menjadi sebuah peluang bagi para pengembang information technology (IT), baik pada platfrom desktop maupun mobile. Android adalah sebuah sistem operasi untuk perangkat mobile berbasis Linux yang mencakup sistem operasi dan aplikasi. Android menyediakan platform terbuka bagi para pengembang untuk menciptakan aplikasi mereka (Safaat, 2014) yang mempunyai macam-macam versi Android dan versi spesifikasi sesuai dengan kebutuhan pengguna Android. Dengan menggunakan Android yang saat ini cakupannya luas, maka penggunaan aplikasi program diet ini akan mudah dicapai oleh pengguna.

Permasalahan yang terjadi saat ini adalah program diet masih dilakukan manual dan tidak dipilih dengan tepat, sehingga mempersulit olahragawan 


\section{Journal of Software Engineering Ampera}

Vol. 1, No. 1, February 2020 e-ISSN: 2775-2488

https://journal-computing.org/index.php/journal-sea/index

untuk dapat menjalani program diet secara efektif karena tidak sesuai dengan jenis olahraga yang mereka geluti. Maka diperlukan aplikasi yang mampu membimbing untuk mendampingi program diet berbasis Android, juga dapat membimbing dan mengingatkan pengguna untuk menjalani aktivitas diet.

Berdasarkan uraian dan latar belakang di atasmaka penulis akan membuat aplikasi berbasis Android dengan judul"Aplikasi Program Diet Berdasarkan Jenis Olahraga Berbasis Android".

\section{METODOLOGI PENELITIAN}

Menurut Sugiyono (2013) Metode penelitian pada dasarnya merupakan cara ilmiah untuk mendapatkan data dengan tujuan dan kegunaan tertentu. Berdasarkan hal tersebut terdapat empat kata kunci yang perlu diperhatikan yaitu cara ilmiah, data, tujuan dan kegunaan. Menurut Darmadi (2013), Metode penelitian adalah suatu cara ilmiah untuk mendapatkan data dengan tujuan kegunaan tertentu. Cara ilmiah berarti kegiatan penelitian itu didasarkan pada ciri-ciri keilmuan yaitu rasional, empiris, dan sistematis. Berdasarkan pemaparan di atas dapat disimpulkan bahwa metode penelitian adalah suatu cara ilmiah untuk memperoleh data dengan tujuan tertentu.

Metode yang digunakan oleh penulis adalah metode deskriptif. Metode deskriptif adalah suatu metode dalam meneliti status sekelompok manusia, suatu objek, suatu set kondisi, suatu sistem pemikiran, ataupun suatu peristiwa pada masa sekarang. Tujuan dari penelitian deskriptif ini adalah untuk membuat deskriptif, gambaran atau lukisan secara sistematis, actual dan akurat mengenai fakta-fakta, sifat-sifat serta hubungan antar fenomena yang diselidiki.

\subsection{Metode Penelitian}

Metode pengumpulan data yang digunakan dalam penelitian tugas akhir ini adalah:

1) Observasi

Metode dokumen merupakan metode yang dilakukan dengan cara mengamati langsung keadaan dan kegiatan, guna mendapatkan keterangan yang akurat.

2) Studi Pustaka

Studi Pustaka adalah suatu cara pengumpulan data dengan cara menghimpun informasi-informasi yang relevan dengan topik atau masalah yang diteliti. Peneliti mendapatkan data-data tersebut dari 


\section{Journal of Software Engineering Ampera}

Vol. 1, No. 1, February 2020 e-ISSN: 2775-2488

https://journal-computing.org/index.php/journal-sea/index

buku-buku pembuatanaplikasi andorid, masalah-masalah dan informasi tentang pembayaran dan teknologi informasi di Android.

\subsection{Metode Pengembangan Sistem}

Menurut Pressman (2010:43) model evolusiooner bersifat interatif,di tandai dengan cara yang memungkinkan anda mengembangkan versi prangkat lunak yang lebih lengkap pada paragraf berikut, proses evolusi yang umum.

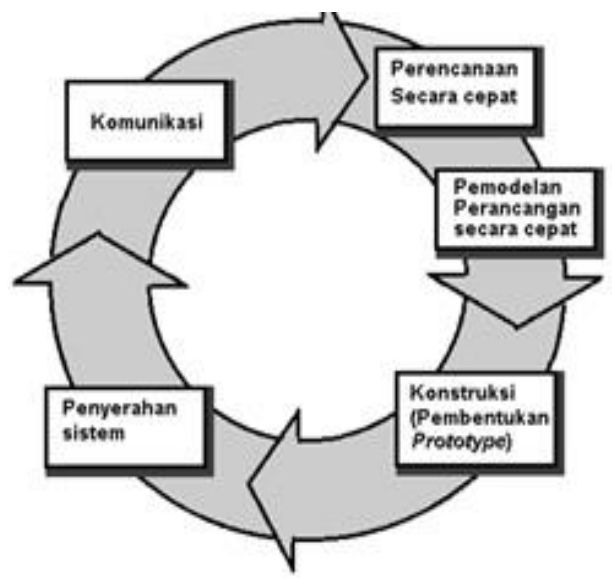

Sumber: Pressman, 2010

Gambar 1. Metode Prototyping

Metode prototyping sebagai suatu paradigma baru dalam pengembangan sistem informasi manajemen, tidak hanya sekedar suatu evolusi dari metode pengembangan sistem informasi yang sudah ada, tetapi sekaligus merupakan revolusi dalam pengembangan sistem informasi manajemen. Selain itu, untuk memodelkan sebuah perangkat lunak dibutuhkan beberapa tahapan di dalam proses pengembangannya adalah sebagai berikut :

1) Komunikasi, Pengembang mendefinisikan format dan kebutuhan keseluruhan perangkat lunak, mengidentifikasikan semua kebutuhan, dan garis besar sistem yang akan dibuat.

2) Perancangan secara cepat, Membangun prototyping dengan membuat perancangan sementara yang berpusat pada penyajian kepada pelanggan (misalnya dengan membuat input dan contoh outputnya).

3) Pemodelan perancangan secara cepat, Evaluasi ini dilakukan oleh pelanggan apakah prototyping yang sudah dibangun sudah sesuai 


\section{Journal of Software Engineering Ampera}

Vol. 1, No. 1, February 2020 e-ISSN: 2775-2488

https://journal-computing.org/index.php/journal-sea/index

dengan keinginan pelanggan. Jika sudah sesuai maka langkah keempatakan diambil. Jika tidak, maka prototyping diperbaiki dengan mengulang langkah 1, 2 , dan 3.

4) Konstruksi (pembentukan prototyping), Dalam tahap ini prototyping yang sudah disepakati diterjemahkan kedalam bahasa pemrograman yang sesuai.

5) Penyerahan sistem, Setelah sistem sudah menjadi suatu perangkat lunak yang siap pakai, harus dites dahulu. baik dengan White Box, Black Box, maupun Basis Path, pengujian struktur dan lain-lain.

\section{HASIL DAN PEMBAHASAN}

Aplikasi program diet berdasarkan jenis olahraga berbasis Android adalah perangkat lunak yang ditujukan bagi masyarakat umum yang ingin melakukan kegiatan diet. Pengguna tersebut dapat menggunakan aplikasi untuk mempermudah diet mereka berdasarkan jenis olahraga yang ada. Kegunaan aplikasi program diet berdasarkan jenis olahraga berbasis Android ini yaitu agar pengguna dapat melakukan program diet dengan bantuan smartphone yang berdasarkan jenis olahraga.

Adapun fitur-fitur yang terdapat pada aplikasi program diet berdasarkan jenis olahraga berbasis Android ini yaitu paket-paket diet yang berisi kegiatan olahraga per hari dengan kegiatan olahraga yang dilakukan bervariasi per harinya dengan diselingi istirahat, misalnya Hari 1 melakukan Bench Dip, kemudian di Hari 2 istirahat total dengan catatan tetap melakukan program diet, kemudian di Hari 3 kembali melakukan olahraga, begitu seterusnya sesuai jadwal paket yang dipilih.

Selanjutnya terdapat program diet berupa aturan atau jadwal makan yang dapat diterapkan untuk membantu diet. Jadwal tersebut terdiri dari sarapan, snack pagi, makan siang, snack sore, dan makan malam. Menu makanan maupun minuman pada program diet tersebut telah disesuaikan dengan keperluan diet pengguna. Lalu, terdapat fitur pengingat yang dapat mengingatkan pengguna dalam melakukan olahraga saat menjalani diet. Pengingat tersebut dapat diatur berdasarkan hari dan akan mengeluarkan suara alarm serta pesan notifikasi pada pengguna untuk mengingatkan olahraga yang perlu dilakukan. 


\section{Journal of Software Engineering Ampera}

Vol. 1, No. 1, February 2020 e-ISSN: 2775-2488

https://journal-computing.org/index.php/journal-sea/index

Terakhir, profil yang dapat memuat informasi pribadi pengguna dan dapat diupdate untuk mengubah biodata pengguna tersebut. Terdapat menu yaitu Lihat Biodata untuk melihat detail dari biodata user, dan Update Biodata untuk mengubah dan memperbarui biodata user tersebut. Adapun pada tahapan ini akan ditampilkan hasil tampilan dan telah dilakukan proses coding terhadap aplikasi. Adapun hasil dari tampilan aplikasi program diet berdasarkan jenis olahraga yang telah dibuat dapat disajikan pada struktur berikut:

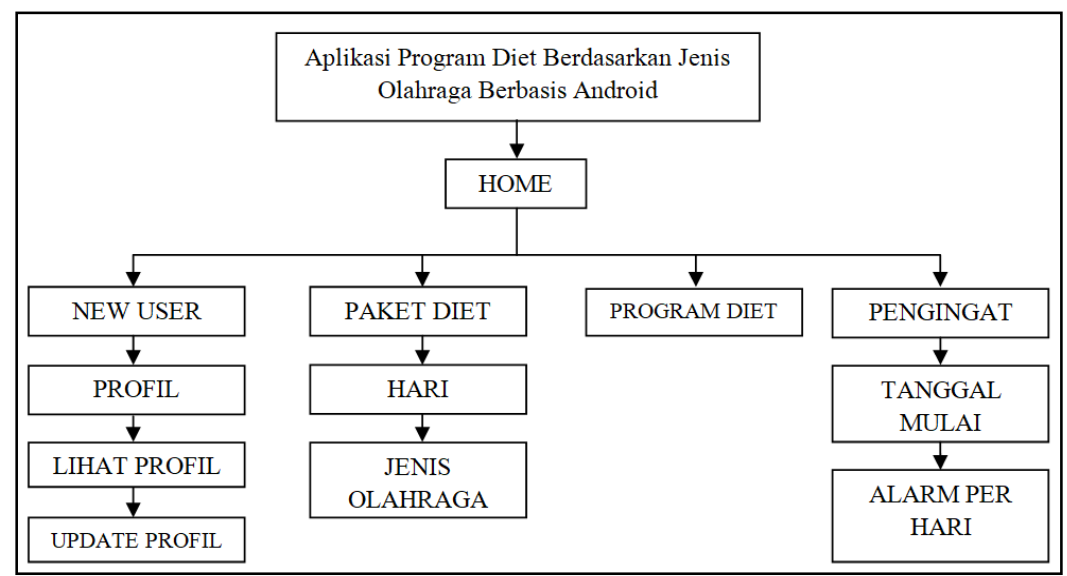

Gambar 2. Struktur Aplikasi Program Diet Berdasarkan Jenis Olahraga Berbasis Android

Struktur di atas merupakan struktur aplikasi program diet berdasarkan jenis olahraga berbasis Android, yang terdiri oleh berbagai bagian. Struktur ini diawali dengan Home yaitu tampilan awal beranda aplikasi. Home kemudian bercabang menjadi New User, Paket Diet, Program Diet, Pengingat. New User merupakan form yang ditampilkan apabila pengguna baru pertama kali menggunakan program. Apabila pengguna sudah pernah, maka dapat mengakses Profil dan melakukan Lihat Profil maupun Update Profil. Selanjutnya, Paket Diet berisi Hari yang memuat beberapa Jenis Olahraga yang dapat dilakukan oleh pengguna.

Selanjutnya, Program Diet yaitu saran resep menu untuk dikonsumsi selama menjalani diet. Terakhir, Pengingat merupakan fitur untuk mengingatkan pengguna tentang program dietnya, yaitu dapat menentukan Tanggal Mulai serta Alarm Per Hari yang terjadwal pada pengingat. Selanjutnya hasil akhir dari tampilan sistem informasi yang telah dibuat adalah sebagai berikut: 


\section{Journal of Software Engineering Ampera}

Vol. 1, No. 1, February 2020 e-ISSN: 2775-2488

https://journal-computing.org/index.php/journal-sea/index

\section{1) Halaman Input Data Awal}

Halaman input data awal merupakan halaman yang menampilkan form untuk diisi oleh pengguna di awal aplikasi, meliputi nama, jenis kelamin, tinggi badan, berat badan, dan berat yang dituju pada aplikasi program diet berbasis Android. Kemudian, pengguna dapat menekan tombol Lanjut untuk menuju ke halaman berikutnya yaitu halaman pilih paket. Berikut adalah tampilan halaman input data awal:

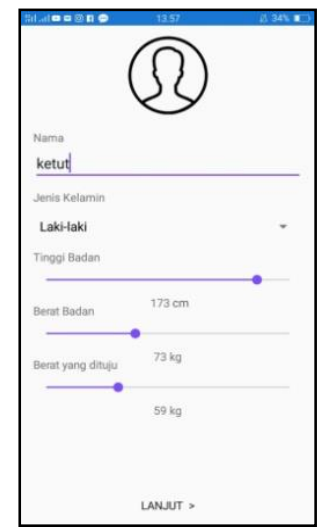

Gambar 3. Tampilan Halaman Input Data Awal

\section{2) Halaman Pilihan Paket}

Halaman pilihan paket merupakan halaman setelah user memasukkan data diri, kemudian menampilkan daftar pilihan paket diet dipilih yang dapat dijalani dalam paket diet tersebut. User dapat memilih paket diet sesuai yang diinginkan, kemudian setelah tombol ditekan, akan menampilkan halaman detail paket.Berikut adalah tampilan halaman pilihan paket diet:

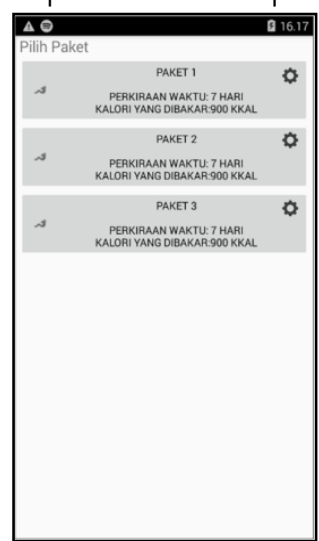

Gambar 4. Tampilan Halaman Pilihan Paket Diet 


\section{Journal of Software Engineering Ampera}

Vol. 1, No. 1, February 2020 e-ISSN: 2775-2488

https://journal-computing.org/index.php/journal-sea/index

\section{3) Halaman Konfigurasi Paket}

Halaman konfigurasi paket merupakan halaman yang menampilkan konfigurasi paket diet yang disertai dengan pengaturan pengingat alarm dan penentuan tanggal mulainya. Setelah itu, pengguna dapat menekan tombol Simpan untuk menuju halaman paket diet setelah dipilih. Berikut adalah tampilan halaman konfigurasi paket diet:

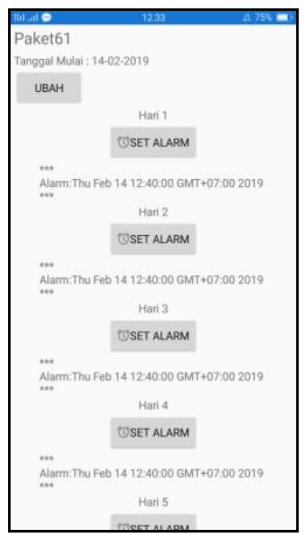

Gambar 5. Tampilan Halaman Konfigurasi Paket

\section{4) Halaman Paket Diet}

Halaman paket diet merupakan halaman yang menampilkan aktivitas pada paket diet yang disediakan pada aplikasi program diet berbasis Android. Aktivitas tersebut berupa olahraga yang perlu dilakukan pada hari tertentu dan kapan harus beristirahat. Berikut adalah tampilan halaman paket diet:

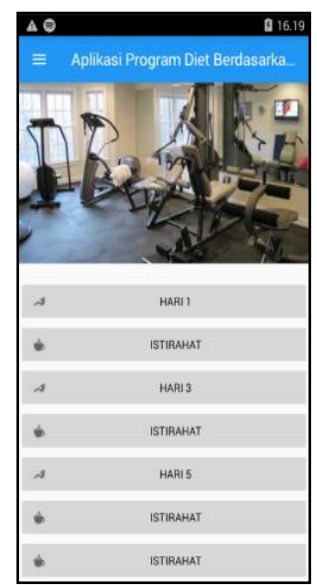

Gambar 6. Tampilan Halaman Paket Diet 


\section{Journal of Software Engineering Ampera}

Vol. 1, No. 1, February 2020 e-ISSN: 2775-2488

https://journal-computing.org/index.php/journal-sea/index

\section{5) Halaman Jenis Olahraga}

Halaman jenis olahraga merupakan halaman setelah paket diet dipilih dan menampilkan daftar jenis latihan olahraga yang dapat dijalani dalam paket diet tersebut. Ketika salah satu dipilih, maka akan menampikan detail dari jenis latihan olahraga tersebut. Berikut adalah tampilan halaman jenis olahraga:

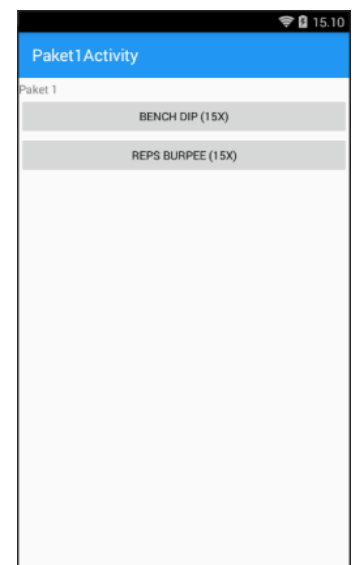

Gambar 7. Tampilan Halaman Jenis Olahraga

\section{6) Halaman Detail Jenis Olahraga}

Halaman detail jenis olahraga merupakan halaman yang menampilkan detail dari jenis olahraga dalam latihan pada paket diet yang disediakan pada aplikasi program diet berbasis Android. Berikut adalah tampilan halaman detail jenis olahraga:

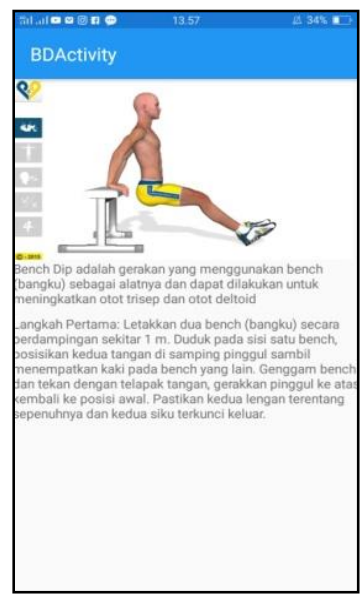

Gambar 8. Tampilan Halaman Detail Jenis Olahraga 


\section{Journal of Software Engineering Ampera}

Vol. 1, No. 1, February 2020 e-ISSN: 2775-2488

https://journal-computing.org/index.php/journal-sea/index

\section{7) Halaman Program Diet}

Halaman program diet merupakan halaman yang menampilkan kepada pengguna berupa program diet menu makanan dan minuman sesuai dengan keperluan diet. Pengguna dapat mendapatkan informasi mengenai program diet yang perlu diterapkan pada sarapan, snack pagi, makan siang, snack sore, dan makan malam. Berikut adalah tampilan halaman program diet:

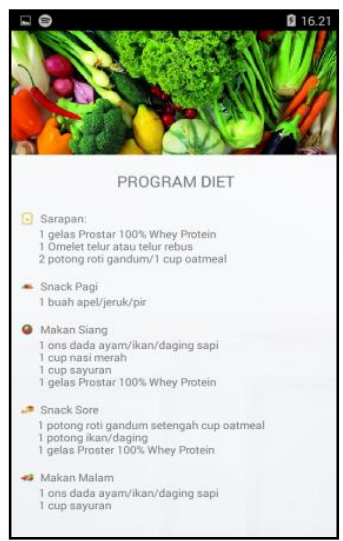

Gambar 9. Halaman Program Diet

\section{8) Halaman Profil}

Halaman profil merupakan halaman yang menampilkan kepada pengguna berupa form pengisian data diri pengguna aplikasi program diet berbasis Android. Terdapat menu yaitu Lihat Biodata untuk melihat detail dari biodata user, dan Update Biodata untuk mengubah dan memperbarui biodata user tersebut. Berikut adalah tampilan halaman profil:

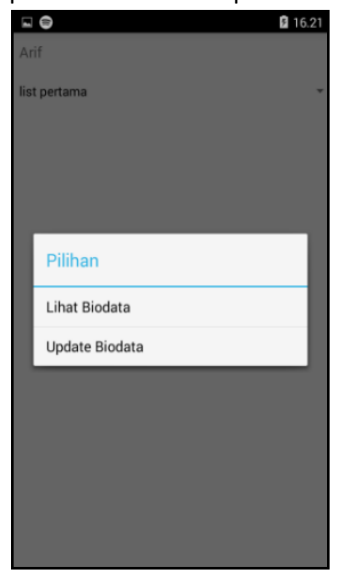

Gambar 10. Tampilan Halaman Profil 


\section{Journal of Software Engineering Ampera}

Vol. 1, No. 1, February 2020 e-ISSN: 2775-2488

https://journal-computing.org/index.php/journal-sea/index

\section{9) Halaman Lihat Biodata}

Halaman Lihat Biodata merupakan halaman yang menampilkan detail biodata dari user yang menampilkan nomor, nama, jenis kelamin, tinggi badan, berat badan, dan berat badan yang dituju. Terdapat tombol Kembali bagi pengguna untuk menuju halaman sebelumnya. Berikut adalah tampilan halaman Lihat Biodata:

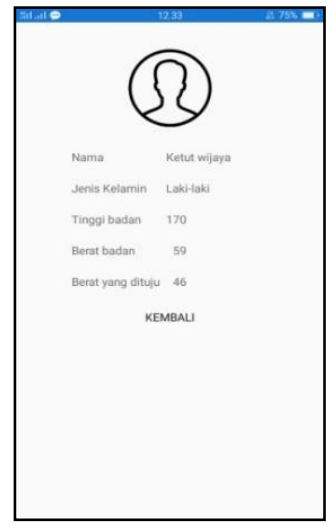

Gambar 11. Halaman Lihat Biodata

\section{0) Halaman Update Biodata}

Halaman Update Biodata merupakan halaman yang menampilkan kepada pengguna berupa form untuk update biodata pada aplikasi program diet berbasis Android. Disini user dapat memperbarui nama, jenis kelamin, tinggi badan, berat badan, dan berat badan yang dituju. Pengguna dapat menyimpan dengan menekan tombol Simpan atau dapat juga pengguna menekan tombol Kembali untuk menuju halaman sebelumnya. Berikut adalah tampilan halaman update biodata:

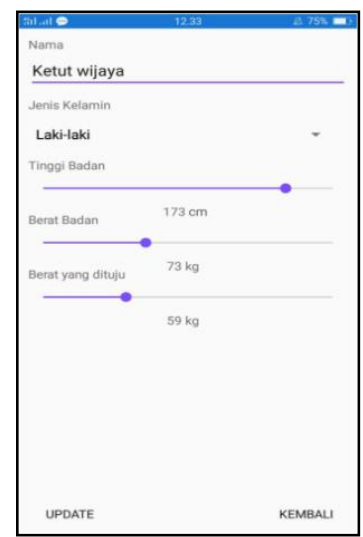

Gambar 12. Tampilan Halaman Update Biodata 


\section{Journal of Software Engineering Ampera}

Vol. 1, No. 1, February 2020 e-ISSN: 2775-2488

https://journal-computing.org/index.php/journal-sea/index

\section{KESIMPULAN}

Berdasarkan hasil dan pembahasan yang telah dibahas pada bab sebelumnya, maka penulis mencoba menarik kesimpulan dan saran yang mungkin kan dapat dijadikan pertimbangan bagi pengguna sebagai berikut :

1) Aplikasi program diet berdasarkan jenis olahraga berbasis Android ini membantu pengguna melakukan program diet melalui perangkat Android dan dapat membantu penerapan metode diet.

2) Aplikasi ini mempermudah pengguna sebagai pengingat program diet bagi pengguna berdasarkan jenis olahraga dengan menggunakan metode pengembangan aplikasi Prototype.

3) Aplikasi ini dibangun sebagai asisten program diet melalui paketpaket diet, dan dibuat menggunakan Android Studio.

\section{DAFTAR PUSTAKA}

Al Fatta, Hanif. 2007. Analisis dan Perancangan Sistem Informasi. Yogyakarta : ANDI.

Amirta, Y. (2007). Diet Sehat, Murah \& Menyenangkan.Yogyakarata: Kreasi Wacana.

Dede Dwi Anggara. 2013. "Pengenalan Android", http://saosusd.blogspot.com. diakses pada tanggal 5 maret 2018.

Elga, Precha. (2007). Hubungan Body Dissastifaction dengan Perilaku Diet pada Remaja. Skripsi tidak dipublikasikan, Fakultas Psikologi, Universitas Indonesia, Depok.

Fitriyanti, Dewi. (2013). Hubungan Tingkat Kesukaan dan Asupan Energi Protein Terhadap Daya Tahan Fisik Siswa Pusat Pendidikan TNI. Jurnal Gizi Indonesia. 32,60-72.

Gandhewar., Nisarg dan Rahila Sheikh. Google Android : An Emerging Software Platform for mobile device.(International Journal On Computer Science and Engineering (IJCSE). 2010. 0975-339.

Jogiyanto, HM, MBA, Akt. 2005. "Analisis dan Desain Sistem Informasi Pendekatan Terstruktur Teori dan Praktik aplikasi Bisnis", Yogyakarta : Andi.

Jones, Charles., 1984. An Introduction to the study of Public Policy. Terjemahan. Jakarta : Rajawali.

Kim, M., \& Lennon, S. J. 2006. Analysis of Diet Advertisement: A Cross National Comparison of Korean and U.S Women's Magazine. Clothing and Textile 


\section{Journal of Software Engineering Ampera}

Vol. 1, No. 1, February 2020 e-ISSN: 2775-2488

https://journal-computing.org/index.php/journal-sea/index

Research Journal. (online). Available FTP:

http://ctr.sagepub.com/egi/reprint/24/4/34.

Nugroho, Adi. 2004. Rational Rose untuk Pemodelan Berorientasi Obyek.

Bandung: Penerbit Informatika

Pressman, R.S. (2010), Software Engineering : a practitioner's approach,.

McGraw-Hill, New York.

Purnomo, Hari. 2004. "Pengantar Teknik Industri". Yogyakarta: Graha Ilmu.

Safaat, Nazruddin. 2014. Android Pemrograman Aplikasi Mobile Smartphone dan Tablet PC Berbasis Android. Bandung: Informatika.

Sajoto. 1988. Pembinaan Kondisi Fisik Dalam Olahraga. Departemen Pendidikan dan Kebudayaan Direktorat Jenderal Pendidikan Tinggi Proyek Pengadaan Buku pada Lembaga Pengembangan Tenaga

Pendidikan. Jakarta.

Sandjaja. dkk. (2009). Kamus Gizi. Jakarta. PT Kompas Media Nusantara

Sugiyono. 2013. Metode Penelitian Pendidikan Pendekatan Kuantitatif, Kualitatif,

Supardi. 2005. Metodologi Penelitian Ekonomi dan Bisnis. Yogyakarta: UII 